\title{
A cremation pit at Howford, Strichen, Aberdeenshire
}

\author{
Moira Greig ${ }^{1}$ \\ with contributions by Sue Anderson ${ }^{2}$, Ann Clarke $^{3}$, Michael Cressey ${ }^{4}$, \\ Jacqueline McKinley ${ }^{5}$ and Dawn McLaren ${ }^{6}$
}

\begin{abstract}
A small emergency excavation was undertaken under extreme conditions in 1984 after receiving a report that a Bronze Age urn was visible in an eroded embankment after a heavy frost. Cremated remains of a female adult and infant, 11 burnt flints, a possible fragment of ivory and five pierced clay ornaments were subsequently recovered from the remains of a cremation pit, but no urn was recorded. A radiocarbon determination $3510 \pm 30$ BP (SUERC-33727) was obtained from birchwood charcoal within the pit and a date from oak charcoal of 3600 \pm 30 BP (SUERC-33728). Unfortunately, a few of these artefacts have been mislaid since deposition in a museum so were unavailable for analysis. The same site produced two other cremation pits, one in 1970 and another later in 1986, which produced a date of $3460 \pm 35$ BP (GrA-28622), suggesting a larger cemetery exists.
\end{abstract}

\section{THE SITE}

Howford Farm lies $c 500 \mathrm{~m}$ south-east from the edge of the village of Strichen at NGR: NJ 9539 5473 , on a moderate west-facing slope at $63 \mathrm{~m}$ OD (Illus 1). A low gravel mound had at some point in the past been cut into to build a track, which runs around the back of a farm building. The east side of the track is now formed by an almost vertical embankment $c 3.10 \mathrm{~m}$ high. After a snow fall, followed by a very heavy frost and sudden thaw, part of this embankment collapsed, revealing the outline of a small pit in the exposed section. When first reported by the farmer an urn was said to be visible in the embankment, but when the excavator arrived the following day no urn was visible.

The same embankment had previously revealed another cremation pit in 1970 (Lockhart 1972: 289-90). A second was found in 1986 (Shepherd 1987) after the revealing of this present one (Canmore ID 20728). Unfortunately all were excavated under similar poor conditions.

\section{THE CREMATION PIT}

The height of the embankment made access to the pit difficult, but cleaning of the exposed bank revealed the top of the pit lying beneath $1 \mathrm{~m}$ of grey/brown loam (Context 001) and cut into the natural yellow sandy gravel (C006). The pit lay $c 2.10 \mathrm{~m}$ above the surface of the track. The northern end of the pit appeared to have been cut by a later animal burial pit (C002) as a few animal bones were visible near the base of this context. However, it was impossible in some areas to distinguish the edge of this burial pit from the grey/brown loam of C001.

\footnotetext{
${ }^{1}$ Lawview, Greenbrig Road, Kilconquhar, Fife KY9 1PA

${ }^{2}$ Spoilheap Archaeology, 2 Old Laundry Court, Norwich NR2 4GZ

${ }^{3}$ Rockville Lodge, North Berwick EH39 5JN

${ }^{4}$ CFA, Old Engine House, Eskmills Park, Musselburgh, East Lothian EH21 7PQ

5 Wessex Archaeology, Portway House, Old Sarum Park, Salisbury, Wilts SP4 6EB

${ }^{6}$ AOC Archaeology Group, Edgefield Road Industrial Estate, Loanhead, Midlothian EH20 9SY
} 


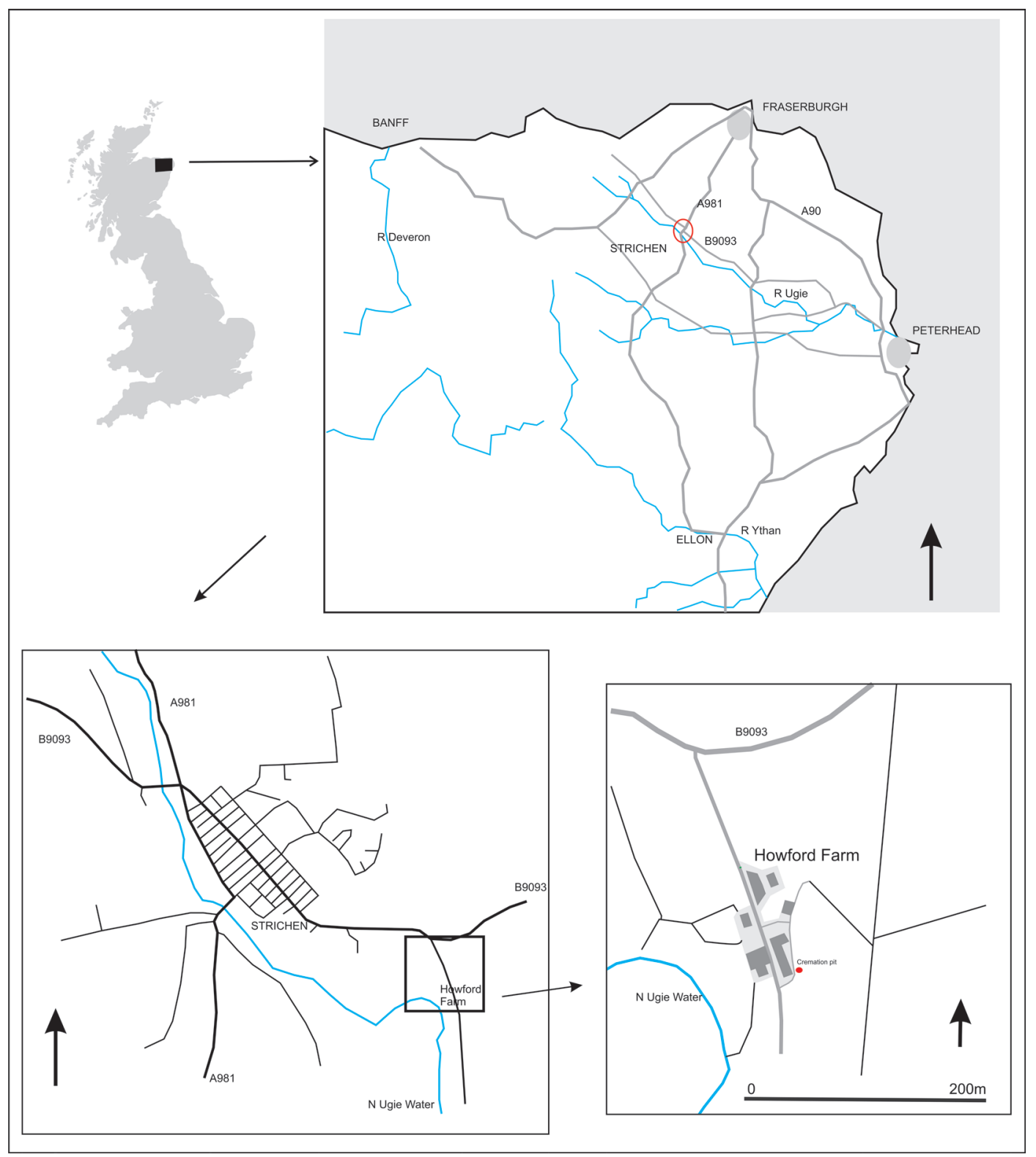

ILlus 1 Location map of the cremation pit at Howford, Strichen

The remains of the cremation pit were $0.94 \mathrm{~m}$ wide by $0.42 \mathrm{~m}$ at its deepest, and consisted of three distinct contexts (Illus 2). The upper (C003) was of a dark orange gritty sand, $0.36 \mathrm{~m}$ wide by $0.16 \mathrm{~m}$ deep and may have originally effectively sealed the pit prior to the intrusion of the animal burial. Below this was an area of compact orange sandy clay with bright orange patches (C004), which varied in thickness from $10-22 \mathrm{~cm}$. Within it a number of burnt bone fragments and a piece of burnt flint were recorded. This sealed a sticky black layer (C005) 4-14cm thick, lying on top of 

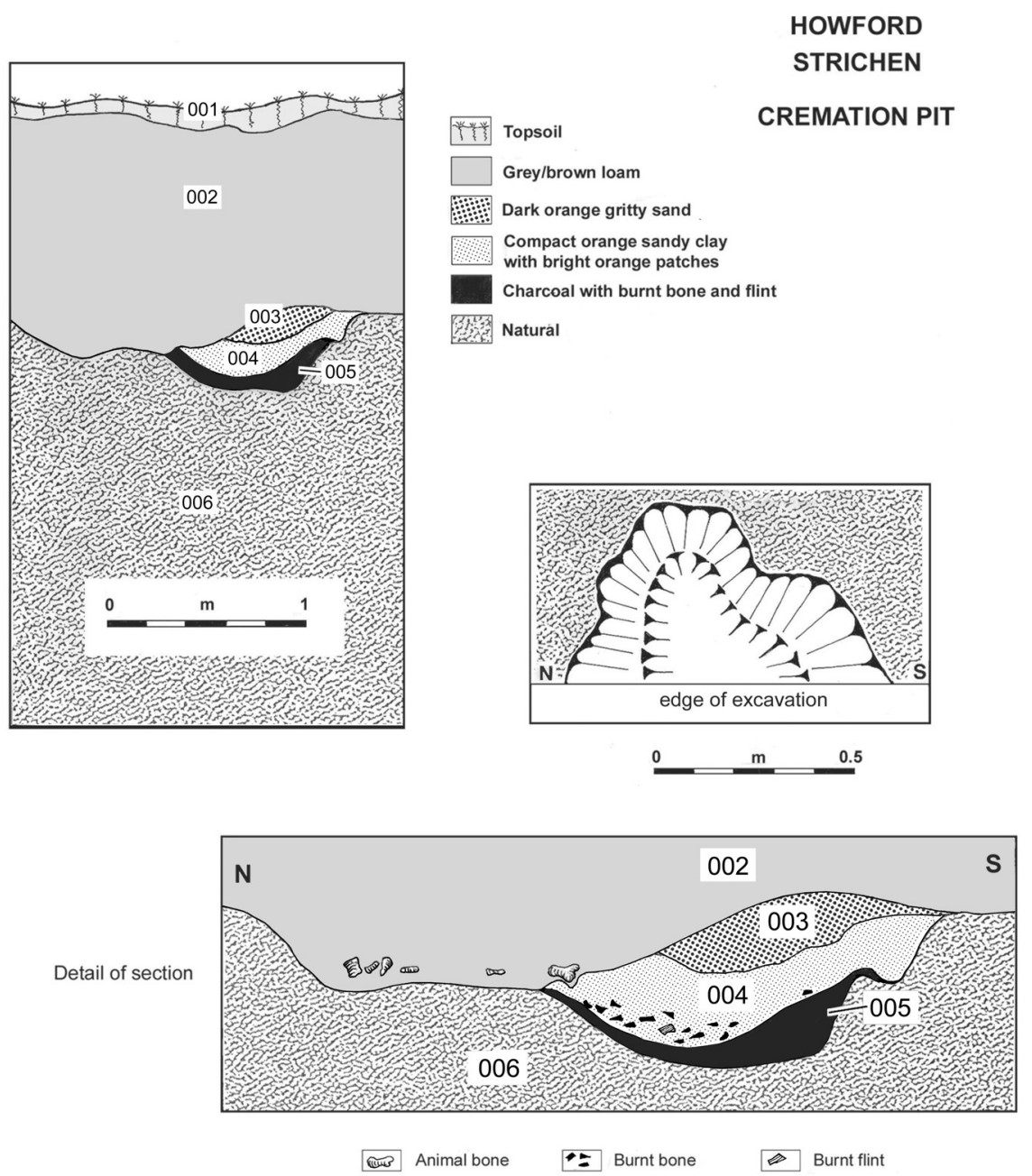

ILLUS 2 Section and plan of the remains of the cremation pit at Howford, showing the contexts

the base of the pit. Numerous pieces of calcined bone were visible throughout this context, although less concentrated in the south end than elsewhere. Only a few charcoal fragments were recovered.

Due to excavation work being undertaken in extremely poor weather conditions, and the possibility of further collapsing of the embankment imminent, each context was bagged separately and later dry sieved, from which more bone was recovered. A plan of the remains of the empty pit was drawn (see Illus 2) but only an estimate of the size of the original pit can be suggested as $c 0.85 \mathrm{~m} \times 0.90 \mathrm{~m} \times 0.45 \mathrm{~m}$ deep.

The material from the base of the collapsed embankment below the pit was also bagged and later sieved. From this, three whole and two half clay ornaments and a number of burnt flints were recovered. Unfortunately it is not possible to indicate in which context these clay artefacts or flints lay within the pit. No evidence of any surviving urn or other pottery fragments was recovered during the sieving process, so it is 
unclear what type of urn - if any - may have been deposited in the pit.

All artefacts were later deposited in a local museum and the bones sent to a bone specialist. However, the bones were either not returned to the museum after being studied, or have been misplaced since, so a further report on the possible ivory fragment found with the bones is not available. Also, unfortunately, the two half clay ornaments appear to have been separated from the three complete clay objects and somehow misplaced in the museum, so a full report on all artefacts is not possible. However, it is fortunate that clay objects $\mathrm{C}$ and $\mathrm{D}$ were illustrated along with the other three before being deposited in the museum, so there is at least a record of them.

\section{THE BONES}

\section{Jacqueline McKinley}

The material was recovered from three different contexts, as well as the unstratified, collapsed material from below the pit, and produced identifiable remains from all four body areas. The remains were those of two individuals, a mature adult aged $c$ 25-35 years, probably female, and an infant aged 2-4 years.

The infant bone was recovered from $\mathrm{C004}$ and $\mathrm{C} 005$ and the adult bone was spread between C003, C004 and C005. No obvious deliberate distribution was evident. No pathology was recorded. The bone was generally very chalky and white except for four, which were very hard. Firing was fairly good and the bone was well fragmented. A worked bone object, also burnt, was recovered from $\mathrm{C} 005$, as was some burnt animal bone and some possible ivory fragments.

A total weight of $847.6 \mathrm{~g}$ of bone was recovered, with a maximum fragment size of $70 \mathrm{~mm}$. Of this, $46.5 \%$ was $>10 \mathrm{~mm}$ in size, $38.8 \%$ was $>5 \mathrm{~mm}$ and the remainder was $>2 \mathrm{~mm}$. Identifiable bone amounted to $150.5 \mathrm{~g}(17.7 \%$ of the total weight, of which $52.1 \%$ was skull, $13.9 \%$ was axial. $11.6 \%$ was upper limb bone and $22.4 \%$ was lower limb). Most of this belonged to the adult and included tooth fragments, pieces of maxilla, mandible and cranial vault, vertebrae, the sciatic notch of the pelvis (wide) and fragments of all major limb bones, hands and feet.
A few bones recovered from the unstratified, collapsed material were studied at a later date. These included an unfused proximal epiphysis of radius, indicating age of $11-15$ if female, and 1317 if male; a fragment of skull vault; a fragment of possibly petrous pyramid part of temporal area of skull; two fragments of long bone, $68.2 \mathrm{~mm}$ and $41.3 \mathrm{~mm}$ respectively; three unidentifiable fragments $25 \mathrm{~mm}, 15.3 \mathrm{~mm}$ and $14.2 \mathrm{~mm}$ long respectively (Aida Romera pers comm).

\section{THE FINDS}

\section{LITHICS}

Ann Clarke

All of the flints were calcined; ie, burnt white in colour and the extreme heat damage also caused fragmentation and spalling to all the pieces.

Two scrapers (not illustrated) were made from thick secondary flakes with steep, almost invasive retouch around part of the perimeter. The other flints are either simple flakes $(n=4)$ or heat spalls $(n=4)$ and there was one small chip. Just one flake shows evidence of manufacturing technique and this is a core trimming flake from a flat platform flake core. Pebble cortex was present on both of the scrapers as well as four of the flakes and spalls indicating that rolled flint nodules were selected for knapping.

Most of the flints came from C003; a flake came from C004 and the small chip from C005. One scraper came from dry sieving bag 2 with no context number, which was recovered from the collapsed material. The distribution suggests that the flints were part of a more general spread of burnt material, including flint and bone which was deposited in the pit over the main cremated remains.

Flint is not always reported as being found with cremations but the contents of a cordoned urn found at Seggiecrook, Kennethmont, some 100 years previously included artefacts of calcined flint, one of which was reported to be a scraper (Callander 1905: 185). Finished tools of calcined flint - such as knives, scrapers and barbed-and-tanged arrowheads - have been 
occasionally found in cremation deposits inside urns (Shepherd \& Cowie 1977) and it would appear that scrapers were the most common tool form for inclusion. At Brackmont Farm, Leuchars, a group of at least six burnt scrapers were found together with four other flakes associated with the contents of a cordoned urn (Spence 1949). This leads to questions as to how the flint was used in the funerary ritual. The calcined flint was undoubtedly burnt with the full heat of the cremation but the evidence from this pit would suggest that the flints were not too near to the body, or at least were not collected up with the main portion of cremated bones as they were part of the upper sandier deposit. Afterwards they were included with the cremated remains in the pit or urn. Occasionally non-burnt flint tools were included for burial at this stage (Shepherd \& Cowie 1977). The inclusion of flakes with steep scraper edges is an interesting feature of cremation deposits at this period and further research on the deposition of flint assemblages in both 'domestic' and funerary contexts of this period may illuminate the reasons behind their association with cremation.

\section{A}
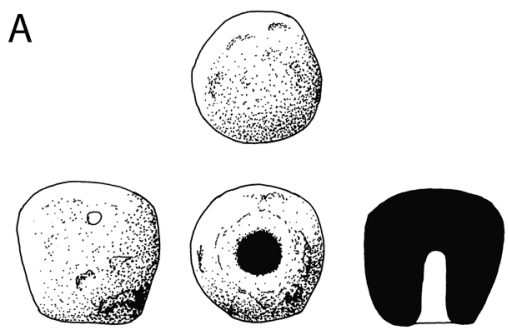

C
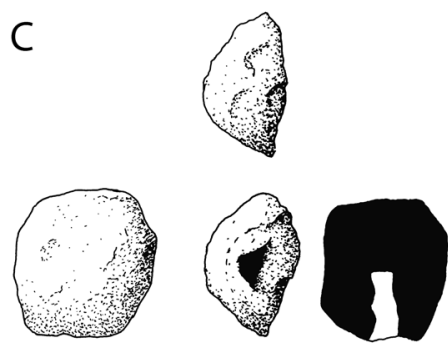

E
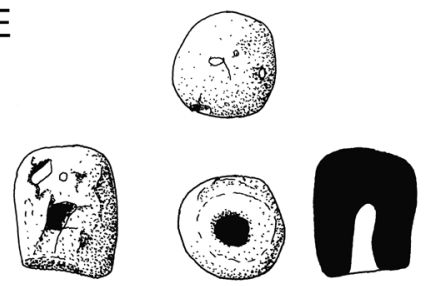

B
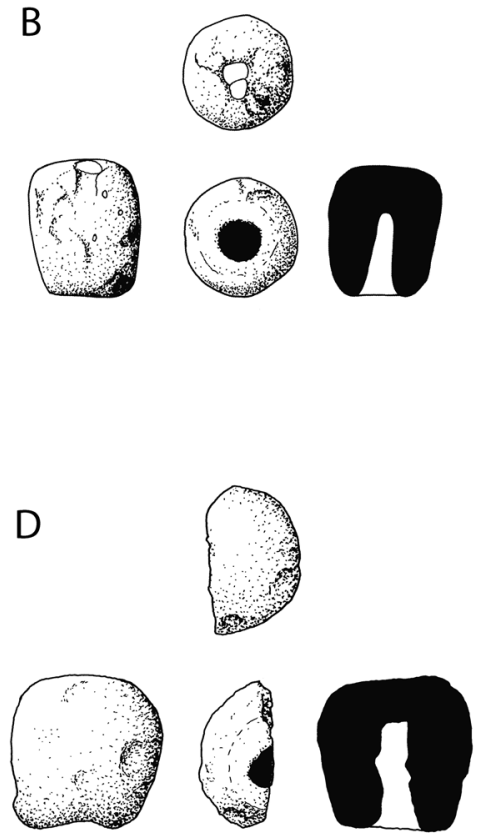

ILLus 3 The fired clay artefacts, recovered from later sieving of the collapsed material 


\section{PIERCED CLAY ORNAMENTS}

\section{Dawn McLaren}

\section{Introduction}

Five small globular and barrel-shaped pierced fired clay objects were found in association with the deposit of cremated human remains (Illus 3 ). All five objects, consisting of three complete examples and two fragmentary pieces, were recovered from soil samples collected from the grave pit and processed after the excavation. As the objects were not identified in the field, their position in relation to the cremation deposit is uncertain but their recovery from sediment, rather than from the burnt remains, implies separation from the bone. Ceramic objects other than pots are very rare in Bronze Age Scotland and the form of these particular objects is difficult to parallel, but they are likely to be terminals from toggle-type ornaments or dress fasteners.

\section{Discussion}

Only the three complete examples were available for examination and they are catalogued in Table 1. They consist of small, hand-shaped tapering pieces of fired clay which vary subtly in shape from globular (A) to cylindrical or barrel-shaped (B \& E), but all are of similar size and form. The centre of the narrowest end of each has been pierced by a single narrow hole (ranging in diameter from $3 \mathrm{~mm}$ to $4.2 \mathrm{~mm}$ ) which runs longitudinally through, but does not completely perforate, the object. The fact that the hole does not pass all the way through suggests that the holes were designed to hold the head of a projecting shaft. The holes in each are not perfectly cylindrical: one is oval and the other two are sub-circular with slightly flattened facets; either this shape reflects the sub-circular section of the inserted shank or else was perhaps designed to prevent a cylindrical shank from rotating. Nondestructive ED-XRF analysis of the Howford objects by Dr Susanna Kirk (formerly of National Museums Scotland, Conservation and Analytical Research Department) revealed no trace of metal within the holes to indicate the former presence of a copper or bronze shank, suggesting that the sub-circular sectioned attachment was organic.

All three of the examined objects have been burnt after initial firing, indicating that they had passed through the funerary pyre. The degree of firing varies considerably between the three objects: $\mathrm{E}$ is the most severely heat-affected, being cracked and discoloured from contact with the fire; $\mathrm{A}$ is the least affected having only slight traces of sooting at the pierced end, implying that it had been protected from the most intense heat of the pyre.

TABLE 1

Catalogue of the clay toggles found at Howford, Aberdeenshire

\begin{tabular}{|c|l|c|c|c|c|c|}
\hline \multirow{2}{*}{ Catalogue } & \multicolumn{1}{|c|}{ Form } & $\begin{array}{c}\text { Height } \\
(\mathrm{mm})\end{array}$ & $\begin{array}{c}\text { Diam } \\
(\mathrm{mm})\end{array}$ & $\begin{array}{c}\text { Mass } \\
(\mathrm{g})\end{array}$ & $\begin{array}{c}\text { Hole } \\
\text { diam } \\
(\mathrm{mm})\end{array}$ & $\begin{array}{c}\text { Hole } \\
\text { depth } \\
(\mathrm{mm})\end{array}$ \\
\hline A & $\begin{array}{l}\text { Globular, tapering, slightly asymmetric; } \\
\text { centrally pierced with an uneven oval } \\
\text { cylindrical hole (not fully perforated) }\end{array}$ & 15 & $10-15$ & 3.09 & $3.5-4.2$ & 8.6 \\
\hline B & $\begin{array}{l}\text { Cylindrical or barrel-shaped, slightly } \\
\text { asymmetric, tapering gently towards narrow } \\
\text { flattened end which is pierced with a sub- } \\
\text { circular hole (not fully perforated) }\end{array}$ & 14.2 & $10.5-11.2$ & 1.83 & 3.2 & 9.5 \\
\hline E & $\begin{array}{l}\text { Tapering cylindrical or barrel-shaped; } \\
\text { narrow end flattened and pierced with sub- } \\
\text { circular hole (not fully perforated) }\end{array}$ & 13.5 & $9.5-10.5$ & 1.43 & $3.0-3.4$ \\
\hline
\end{tabular}


Although they have not been published previously in any detail, these objects have been noted briefly in a wider study which considered aspects of Bronze Age material culture in north-east Scotland (Cowie 1988: 51). Here they were described as 'pinheads' but more recent examination of the objects cannot substantiate this identification. Composite pins with separately produced pinheads are not an ornament type commonly recognised within the British Bronze Age ornament repertoire (although a Late Bronze Age clay mould for a pin head is known from Highstead, Kent (Needham 2007)). Pins with 'fancy' terminals such as crutch-headed, bulb-headed or ring-headed pins of bronze and animal bone are known but are not common and appear to have been very special objects (Woodward \& Hunter 2015: 181). In contrast to these pins just described, the Howford ornaments appear more expediently produced using easily accessible materials and requiring no specialist craft skills or tools to make. If each of the fired clay ornaments from Howford represented a pin, the number associated with one burial would be unprecedented in a later Early Bronze Age context (ibid: 175, table 5.5.1). Decorative domed 'pinheads', made from bone, clay, lignite and stone are known from Iron Age contexts, but these tend to be much larger, grander objects made to surmount iron pin shanks and often have traces of the metal shank surviving (Callander 1921: 121, fig 9:1; CloseBrooks 1986: 166; Hallén 1994: 213, illus 9:10). Looking at all these strands of evidence together, the earlier interpretation of the Howford objects as pinheads does not appear to fit.

An alternative explanation to 'pinheads' could see them as decorative terminals of a toggle-type dress fastener or body ornament, worn in pairs at either end of a simple organic shank, giving them a dumbbell-shaped appearance. It is unclear whether the two broken fragments (not available for examination at the time of writing) are pieces of two separate objects, or a single example. Both of the broken fragments appear to be of squat globular form, like example $\mathrm{A}$, and are quite different in shape from both $\mathrm{B}$ and $\mathrm{E}$. This could suggest that the two incomplete pieces are fragments of a second globular example; a pair to example A. This possible pairing of objects is reinforced by the difference in fabric observed between the two forms: the globular example is a fine-grained, sandy clay with occasional rock inclusions, whereas the cylindrical/barrel-shaped objects are less sandy in composition and have more frequent quartzite inclusions.

As terminals for dumb-bell shaped toggles, the Howford pierced clay ornaments compliment the growing suite of simple toggles and other dress fasteners associated with deposits of Early Bronze Age cremated human bone (McLaren 2007). The term 'toggle' covers a wide array of ornament shapes and these most commonly survive in bone or antler which have been preserved as the result of being burnt on the funeral pyre with the deceased, although unburnt examples are known (Woodward \& Hunter 2015: 121-3; McLaren forthcoming a \& b). A small, damaged, solid, tripartite bone toggle from Acharn cairn, Argyll, may have functioned in a similar way to the proposed toggles from Howford (Ritchie \& Thornber 1975: 17, fig 6a).

Only one similar collection of clay objects is known from a deposit of cremated bone at Seggiecrook, Aberdeenshire (Callander 1908). The cremated human bone was contained within a cinerary urn and was accompanied by a group of unburnt and burnt grave goods, including seven pierced clay objects, burnt flints and a bone toggle. Six of these clay ornaments were of squat cylindrical form with holes pierced transversely through the side of the object; the seventh was a small conical example, with a hole sunk in the centre at the top of the cone (ibid: 214-16, fig 2). Callander's description of the piercing suggests that in each case, the hole did not fully perforate the thickness (ibid: 215). Although these are different in shape from the Howford ornaments and pierced transversely rather than longitudinally, the Seggiecrook examples are comparable in size (approximately $18 \mathrm{~mm}$ in height and $7 \mathrm{~mm}$ in diameter) and are likely to have had a similar decorative purpose. A sample of cremated human bone from another of the Seggiecrook cremations (Callander 1905) was radiocarbon dated in 2002, providing an assay of $3495 \pm 45$ вP (GrA-19427, 1940-1690 cal вC at $2 \sigma$ (Sheridan 2006: 183)). 
Two small round clay pieces, identified as possible pre-bored beads, are reported to have been found in association with a later Bronze Age cremation at Shrubsoles Hill, Kent (Macpherson-Grant 2003: 43). It is unclear from the description whether these were perforated but may be similar in form and function to the Howford and Seggiecrook examples.

Looking more broadly, ceramic ornaments rarely accompany Bronze Age graves and where noted, consist of clay beads, studs or plugs and other miscellaneous, not well understood, items (Longworth 1984: 56; Brindley 2007; Woodward, Hunter \& Bukach 2015: 497). Only a few examples of clay ornaments from Scotland are known. These include a small decorated pottery sphere from a cremation at Kiltry Knock, Alvah (Shepherd \& Cowie 1977: 117-18, fig 3:2), and a possible clay bead necklace reportedly found with an urned cremation burial at Backhill, Newton, Aberdeenshire, in 1863 (Ordnance Survey Name Book 1866: 25).

Farther afield, collections of clay beads come from primary deposits within Winterbourne Stoke G64a barrow, Wiltshire (Annable \& Simpson 1964: 61, no. 481; Woodward \& Hunter 2015: 411-12), from deposits of cremated bone at Kimpton and Twyford Down, Hampshire (Davies 1981: 185, fig 23; Laidlaw 2000: 812, fig 31: 9 \& 10), Crig-a-mennis, Cornwall (Christie 1960: 85, fig 5), and Llanfihangel Nant Brân, Wales (Savory 1980: 155, fig 51: no. 42), and a necklace of biconical beads accompanied a cremation burial at Burtown Little, Co Kildare (Alison Sheridan pers comm). An identical clay object was found in another Bronze Age grave at Tomfarney, Co Wexford (Alison Sheridan pers comm), and a necklace of fusiform and chunky beads comes from Altanagh, Co Tyrone, found alongside a deposit of cremated bone, a cordoned urn, a bronze boss, fossil and two flint blades and has dated to $3360 \pm 30 \mathrm{BP}(\mathrm{GrN}-11449)$ (Williams 1986: 66, fig 27; Brindley 2007: 147).

A handful of stud ornaments or plugs made of fired clay from southern Britain are also known. Although more commonly found in jet or jet-like materials, several clay examples have also been found and recent re-analysis suggests that the studs functioned as ear studs or lip labrets rather than dress fasteners as traditionally thought (Woodward, Hunter \& Sheridan 2015: 182-6, table 5.6.2).

\section{Conclusion}

The majority of clay ornaments associated with Bronze Age burials in Britain are possible dress fasteners which were worn and displayed on the body. The identification of such objects in burial contexts of this date is rare, but this is likely to reflect limited preservation and a lack of recognition rather than a genuine rarity during the Bronze Age. Although not well understood and difficult to parallel, the pierced clay objects from Howford, interpreted here as toggle terminals, are a useful addition to the known repertoire of Bronze Age ornaments recovered from cremations in northern Britain.

\section{FIRED CLAY}

\section{Sue Anderson}

Twenty-four fragments (181g) of fired clay were collected from C004 within the pit, the layer which contained the cremated bone. The pieces were rounded lumps with no surviving surfaces, but they are not consistent with prehistoric pottery (Johnson pers comm). They were all in the same fabric, tempered with medium quartz sand, sparse coarse quartz and sparse sandstone pebbles. Fragments were generally oxidised to an orangebrown, although some thicker pieces had grey areas of reduction. There were no impressions of wattles or other structural elements and no adjoining fragments. Three of the larger pieces, measuring up to $25 \mathrm{~mm}$ in thickness, appeared to have been roughly smoothed to create one flat side.

Clay was used for a variety of purposes which may have resulted in it becoming fired (either intentionally or accidentally). These include metal moulds, loom weights, oven domes and hearth linings, as well as the more unusual objects such as the clay 'pinheads' reported above. The presence of this type of material in a cremation burial is unusual and its function and purpose here are uncertain. Whilst it could potentially represent a sample of the burnt clay surrounding a fire pit below the pyre, the material is abraded 
and it seems more likely that it represents redeposited material from earlier activity on the site, the most likely use being as an oven dome.

\section{CHARCOAL}

\section{Michael Cressey}

Charcoal recovered from the basal fill (C005) of a cremation pit has been identified to recover suitable fragments for radiocarbon dating. The charcoal probably represents the residue from the cremation pyre.

The size of the charcoal examined measured $<4 \mathrm{~mm}$. Identifications were carried out using a binocular microscope at magnifications ranging between $\times 10$ and $\times 200$. Identifications were carried out on transverse cross-sections. Anatomical keys listed in Schweingruber (1992) and in-house reference charcoal were used to aid identifications. Asymmetry and morphological characteristics were recorded. In general, the charcoal was amorphous and blocky, no branchwood charcoal was present.

Two species of wood are represented from the charcoal recovered from within C005. Quercus (oak) and Betula (birch) are present but in such low frequencies that they do not allow any valid judgements on species abundance.

\section{Radiocarbon dates}

Two samples from C005 were submitted to SUERC. The results of the radiocarbon analysis are shown in Table 2.

The oak has produced a slightly older date range than the birch, although the two overlap. Oak was the most abundant charcoal in the burial and may have been used for the pyre itself, but could have been old at the time it was used. In addition, the fired clay from the burial may be residual and it is possible that the oak charcoal was re-deposited with this rather than being associated with the cremated bone. It is suggested that the birch provides a more reliable date for the burial.

\section{DISCUSSION}

While this publication reports on the finding of the remains of one cremation pit at Howford (referred to here as Howford 3), there are definite indications to suggest that a cremation cemetery of unknown extent is situated here. In March 1970 an inverted cinerary urn was found in the embankment behind Howford Farm after weather erosion exposed it (Lockhart 1972: 289-90). The urn lay $c 1 \mathrm{~m}$ under the ground surface, but there are no further details available regarding contexts, or size and shape of any associated pit. The urn belongs to the collared class of cinerary urn and is decorated with twisted cord impressions. It contained the cremated bones of several individuals. Although the bones were 'very comminuted', the lowest fragment of an ulna suggested that one person represented must have been over 20 years old, possibly an adult male. The calcined remains of approximately 20 teeth represent an infant of two years, but other pieces of skull bones represent intervening years. Unfortunately no ${ }^{14} \mathrm{C}$ date is available for this cremation pit (referred to here as Howford 1).

Later, in April 1986, a collapse of the same bank exposed another cinerary urn (referred to as Howford 2), undecorated, with the base

TABLE 2

Radiocarbon dates

\begin{tabular}{|c|c|c|c|c|c|c|}
\hline $\begin{array}{c}\text { SUERC Lab } \\
\text { No. }\end{array}$ & Context & Species & $\begin{array}{c}\text { Radiocarbon age } \\
\text { uncal } B P\end{array}$ & Cal date $(1 \sigma)$ & Cal date $(2 \sigma)$ & $\delta^{13} C$ \\
\hline 33727 & $005 \mathrm{~s} .1$ & Betula & $3510 \pm 30$ & $1890-1770 \mathrm{BC}$ & $1920-1740 \mathrm{BC}$ & $-26.1 \%$ \\
\hline 33728 & $005 \mathrm{~s} .2$ & Quercus & $3600 \pm 30$ & $2020-1910 \mathrm{BC}$ & $2040-1880 \mathrm{BC}$ & $-26.0 \%$ \\
\hline
\end{tabular}


uppermost, although part of the side had eroded away (Shepherd 1987). The skull bones had been laid carefully in the urn as a first deposit, and then other bone fragments, which reduced in size towards the mouth of the urn where charcoal fragments increased. This would suggest that the large recognisable bones were picked out of the pyre first and then the rest swept up with ashes. Dating from charcoal is $3460 \pm 35 \mathrm{BP}$ (GrA-28622, 1880-1690 cal BC at $1 \sigma$ or $1880-$ $1680 \mathrm{cal} \mathrm{BC}$ at $2 \sigma$ ). The bones were thought to belong to one individual, probably a female aged 25-30 years old.

The pit of Howford 3 was discovered after the initial reporting of an urn by the same farmer, again after exposure by weather erosion of the same bank, but no evidence of an urn, or any pottery fragments were recovered from the material bagged at the site (Greig \& Inglis 1984: 13). It must therefore be assumed that the urn was removed by persons unknown within the short time between the reporting and the recording of the site by the excavator the following day. It is unlikely to have been misidentified, as the farmer had already identified and reported urns exposed on the previous two occasions, noted above in 1970 (Lockhart 1972) and later in 1986 (Shepherd 1987). It is therefore unfortunately not possible to say what type of urn was associated with this pit, or how the bones were placed within it.

There is little or no information regarding the pit of Howford 1, or how the bones were placed in the urn. However, from Shepherd's notes on Howford 2, he suggests that after the bones were packed in the urn the pyre debris was swept up and then placed around the urn. This may also have been the case in this later pit of Howford 3, as the burnt flints and some smaller bone fragments were only noted in C004, and not with the major deposit of bones in $\mathrm{C} 005$. However, while flint was only noted lying within C004 it does not necessarily mean that none was deposited in other contexts, as the majority of flints were found later during the sieving of the material, which had already collapsed prior to excavation. Therefore there is a possibility that some may have been deposited in C005 along with the cremated bone. As has been noted by
Clarke above, flints have occasionally been found in cremation deposits inside urns, such as knives, scrapers and arrowheads (Shepherd $\&$ Cowie 1977). Flints are typical of many finds discovered in association with Bronze Age urns from Scotland, but fewer appear to be reported as showing signs of having been affected by heat, apart from those discussed by Shepherd \& Cowie. Interestingly, a burnt flint scraper was also recorded from Seggiecrook (Callander 1905). Other burnt flints were also noted at Skilmafilly near Maud (Johnson \& Cameron 2012: 24-5), where an unenclosed cremation cemetery of 41 pits was uncovered. Here over $80 \%$ of the lithic assemblage was said to have been burnt at high temperatures.

It is unfortunate that the two half clay artefacts noted in the report above have been mislaid or lost - after being deposited in the museum along with the three complete clay ornaments - so a more detailed, complete report cannot be given. The finding of pierced clay 'ornaments' within a cremation pit would appear to be rare in Scotland, apart from those found at Seggiecrook in 1908. Few others have been recorded but, as suggested above, this may be because they have not been identified. Also, the possible re-deposited fired clay is unusual and again may have either not been recognised, or was assumed to have been part of the pyre pit.

It is also unfortunate that the worked bone object, burnt animal bone and the possible ivory fragments do not appear to have been returned to Aberdeen University Geography Department after the human bone report was written, so it has not been possible to obtain a report on these either. These artefacts, however, do appear to have been burnt along with the body and not placed in later. Again at Skilmafilly, a burnt bone artefact was also recorded (Johnson \& Cameron 2012: 26).

There are very few reports which refer to ivory being found in association with Bronze Age burials, although part of an ivory dagger pommel was found by workmen in 1963 at a cist site at Ashgrove Farm, Methilhill, Fife (Henshall 1966: 170-1). This was thought to be ivory from the tooth of a sperm whale. None, as far as the writer is aware, has been found 
in cremation pits. It is possible, however, that burnt ivory has not been recognised in the past for what it was.

\section{CONCLUSION}

At Howford we have a cremation cemetery of unknown extent from which three cremation pits have been recorded. These contained the cremated remains of both young adults and an infant. However, from the one pit alone came a number of relatively rare artefacts, including burnt flints, fired clay artefacts, part of a worked bone object and an ivory fragment. While the date from the oak charcoal of Howford 3 gives a slightly earlier date $(3600 \pm 30$ BP) and may not have been part of the cremation process itself, from the dating of birchwood charcoal from Howford $3(3510 \pm 30$ BP) and Howford $2(3460 \pm 35$ вP) the cemetery would appear to have been in use over a reasonable period of time. Unfortunately, none of the reported cremations were excavated under good conditions, all being exposed through weather erosion. It is quite possible therefore that further bank erosion will expose more cremations in the future.

\section{ACKNOWLEDGEMENTS}

Dawn McLaren is very grateful to Susanna Kirk (NMS Conservation and Analytical Research Department) for her analysis of the clay objects and would like to extend special thanks to Alison Sheridan for her advice and comments on an earlier draft of this paper. Thanks also go to Trevor Cowie, Stuart Needham, Ann Woodward and Peter Woodward for their valuable comments.

Moira Greig would like to thank fellow contributors, especially Sue Anderson for arranging the above reports. She would also like to thank Hilary Murray and Lecky Shepherd for help with illustrations 1 and 2; the late Ian Shepherd and Ian Ralston for their assistance and support and arranging for Jacqueline McKinley to study the human bones; finally special thanks to the Aberdeenshire Council Archaeology Service for financial assistance towards publication costs.

\section{REFERENCES}

Annable, F K \& Simpson, D D A 1964 Guide Catalogue of the Neolithic and Bronze Age Collection in Devizes Museum. Devizes: Wiltshire Archaeological \& Natural History Society.

Brindley, A L 2007 The Dating of Food Vessels and Urns in Ireland. Galway: Department of Archaeology, National University of Ireland.

Callander, J G 1905 'Notice of two cinerary urns and a pendant of slate found at Seggiecrook, in the parish of Kennethmont, Aberdeenshire', Proc Soc Antiq Scot 39: 184-9.

Callander, J G 1908 'Notices of (1) the discovery of a fourth cinerary urn containing burnt human bones and other relics at Seggiecrook, Kennethmont, Aberdeenshire, and (2) two small polished stone axes and a flanged spearhead of bronze from Asia Minor', Proc Soc Antiq Scot 42: 212-33.

Callander, J G 1921 'Report on the excavation of Dun Beag, a broch near Struan, Skye', Proc Soc Antiq Scot 55: 110-31.

Christie, P M 1960 'Crig-a-mennis: a Bronze Age barrow at Lisbey, Perranzabuloe', Proceedings of the Prehistoric Society 26: 76-97.

Close-Brooks, J 1986 'Excavations at Clatchard Craig, Fife', Proc Soc Antiq Scot 116: 117-84.

Cowie, T 1988 Magic Metal: Early Metalworkers in the North-East. Aberdeen: University of Aberdeen.

Davies, S 1981 'The beads', in Dacre, M, Ellison, A, Everton, R F, Smith, I F, Davies, S \& Richards, J 'A Bronze Age urn cemetery at Kimpton, Hampshire', Proceedings of the Prehistoric Society 47: 185.

Greig, M K \& Inglis, J 1984 'Howford Farm', Discovery and Excavation in Scotland 1984: 13.

Hallén, Y 1994 'The use of bone and antler at Foshigarry and Bac Mhic Connain, two Iron Age sites on North Uist, Western Isles', Proc Soc Antiq Scot 124: 189-231.

Henshall, A S 1966 'A dagger-grave and other cist burials at Ashgrove, Methilhill, Fife', Proc Soc Antiq Scot 97: 166-79.

Johnson, M \& Cameron, K 2012 'An Early Bronze Age unenclosed cremation cemetery 
and Mesolithic pit at Skilmafilly, near Maud, Aberdeenshire', Scottish Archaelogical Internet Reports 53. https://doi.org/10.9750/ issn.1773-3808.2012.53.

Laidlaw, M 2000 'The fired clay', in Walker, K E \& Farwell, D E Twyford Down, Hampshire: Archaeological Investigations on the M3 Motorway from Bar End to Compton, 199093, 81-2. Winchester: Hampshire Field Club and Archaeological Society.

Lockhart, R D 1972 'Cinerary urn found at Howford Farm, Strichen, Aberdeenshire', Proc Soc Antiq Scot 104: 289-90.

Longworth, I H 1984 Collared Urns of the Bronze Age in Great Britain and Ireland. Cambridge: Cambridge University Press.

McLaren, D 2007 'Bone and antler toggles of the Bronze Age', in Lelong, O \& MacGregor, G The Lands of Ancient Lothian. Interpreting the Archaeology of the A1, 107. Edinburgh: Society of Antiquaries of Scotland.

McLaren, D forthcoming a 'Worked bone toggles', in Suddaby, I M 'Excavation of two Mesolithic post-circles, Neolithic pits and Bronze Age funerary remains at Silvercrest, Lesmurdie Road, Elgin, Moray, 2002', Scottish Archaeological Internet Reports.

McLaren, D forthcoming b 'The worked bone', in Hunter, F Excavations at Deskford, Moray.

Macpherson-Grant, N 2003 'The burnt/baked clay and ceramic objects', in Coles, S, Hammond, S, Pine, J, Preston, S \& Taylor, A Bronze Age, Roman and Saxon Sites on Shrubsoles Hill, Sheppey and at Wises Lane, Borden, Kent. A Landscape of Ancestors and Agriculture by the Swale, 43. Reading: Thames Valley Archaeological Services (Monograph 4).

Needham, S 2007 'Mould fragments', in Bennett, P, Couldrey, P \& MacphersonGrant, N Highstead Near Chislet, Kent: Excavations 1975-1977, 258-65. Canterbury: Canterbury Archaeological Trust.
Ordnance Survey 1866 Object Name Books of the Ordnance Survey (Aberdeenshire), Volume 88.

Ritchie, J N G \& Thornber, I 1975 'Cairns in the Aline Valley, Morvern, Argyll', in 'Small Cairns in Argyll: some recent work', Proc Soc Antiq Scot 106: 15-38.

Savory, H N 1980 Guide Catalogue of the Bronze Age Collections. Cardiff: National Museum of Wales.

Schweingruber, F H 1992 Microscopic Wood Anatomy. Birmensdorf: Swiss Federal Institute for Forest, Snow and Landscape Research.

Shepherd, I A G \& Cowie, T G 1977 ‘An enlarged food vessel urn burial and associated artefacts from Kiltry Knock, Alvah, Banff and Buchan', Proc Soc Antiq Scot 108: 114-23.

Shepherd, I A G 1987 'Howford Farm', Discovery and Excavation in Scotland 1987: 20.

Sheridan, A 2006 'Dating the Scottish Bronze Age: "There is clearly much that the material can still tell us"', in Burgess, C, Topping, P \& Lynch, F M (eds) Beyond Stonehenge: Essays on the Bronze Age in Honour of Colin Burgess, 162-85. Oxford: Oxbow Books.

Spence, L 1949 'Burials at Brackmont Mill and Brackmont Farm, Leuchars', Proc Soc Antiq Scot 83: 224-9.

Williams, B B 1986 'Excavations at Altanagh, County Tyrone', Ulster Journal of Archaeology 49: 33-88.

Woodward, A \& Hunter, J 2015 Ritual in Early Bronze Age Grave Goods. Oxford: Oxbow Books.

Woodward, A, Hunter, J \& Bukach, D 2015 'Chapter 11: object function', in Woodward, A \& Hunter, J Ritual in Early Bronze Age Grave Goods, 496-538. Oxford: Oxbow Books.

Woodward, A, Hunter, J \& Sheridan, A 2015 'Studs', in Woodward, A \& Hunter, J Ritual in Early Bronze Age Grave Goods, 182-6. Oxford: Oxbow Books.

This paper is published with the aid of a grant from Aberdeenshire Council Archaeology Service 